fessed to be only "approximate generalizations," and its scholastic and discursive style which makes it far from easy reading. The book could, with advantage to the ordinary reader, be condensed to one-half or even one-third of its present size.

The work is divided into three parts. The first discusses the general conception of character, the systems of the emotions and sentiments, the part played by will and intelligence as constituents of character, the influence of temperament upon character, and the methods of science of character. The second discusses the tendencies of the primary instincts and emotions, such as fear, anger, joy, sorrow, disgust, surprise, and curiosity. The third discusses the system of desires in their relations to impulse, appetite, and emotion. This last part will be found of especial interest by those students of the social sciences who regard the desires as "the true social forces."

UNIVERSITY OF MISSOURI

Charles A. Ellwood

History of Poor Relief Legislation in Iowa. By JoHn L. GiLLIN. Iowa City: State Historical Society of Iowa, I9I4. Pp. xiv十 404 .

This scholarly study is divided into four parts: (I) "A General Historical Narrative"; (II) "Special Phases of Poor Relief Legislation in Iowa"; (III) "Special Classes of Dependants and State Control"; (IV) "Summary and Suggestions."

The first two divisions of the book constitute a genealogy of Iowa poor relief legislation. They are of interest mainly as affording illustrations of the legislative methods of American frontier states. The author, in summarizing these legal pedigrees, points out (p. I66) the extent to which "laws were taken ready-made from the statute, books of other jurisdictions" in a spirit of "wholesome optimism" but with "reprehensible carelessness" in failing even to attempt in some cases to adapt to pioneer communities the social machinery borrowed from populous states farther east. He is also "impressed with the fact that in the absence of high motives growing out of careful scientific study of poverty and its treatment, economic considerations have largely determined the treatment prescribed" (p. I76). Thus the taxpayer has been saved immediate outlay, but the state has come down into the twentieth century with a very ineffective organization of its care of the insane and of the poor both in almshouses and in their own homes. 
This has been due largely to unwillingness to take the control of these matters out of the hands of the counties and lodge them firmly in the hands of the state board of control. "The chief obstacle in the way of successful public relief work is that centralized supervision has not gone far enough" (p. 325). ". . . . the situation in Iowa is much as it was in Indiana before $1897 "$ (p. 326).

Part III discusses in order the following classes of dependents: normal children; defectives; soldiers, sailors, and marines; the sick; vagrants; etc. In general, normal children and the feeble-minded receive enlightened treatment which contrasts strangely with the obsolete methods still obtaining in the care and control of paupers and insane. In I9I2, I,3I3 defectives (nearly two-thirds of them insane) were still housed in the county poorhouses; moreover, if a poorhouse luckily contains no insane then "there is absolutely no provision for its inspection and regulation by the state" (p. 3I9). The proposals advanced by the author for remedying these and other defects are thoroughly sound and in line with the best effort in other commonwealths. The book is written in a clear and vigorous style and is accurate in detail and broad in conception. The very numerous notes and references are well managed at the end of the volume.

Dartmouth College

ERville Bartlett Woods

\section{Report of the City Council Committee on Crime of the City of Chicago.} Chicago, I9I5. Pp. I96.

In the space available it is impossible to give a review of the report of Alderman Merriam's committee that will bring out in detail the value of the exhibits.

A few selections from the findings follow:

"The amount of crime in Chicago is rapidly increasing."

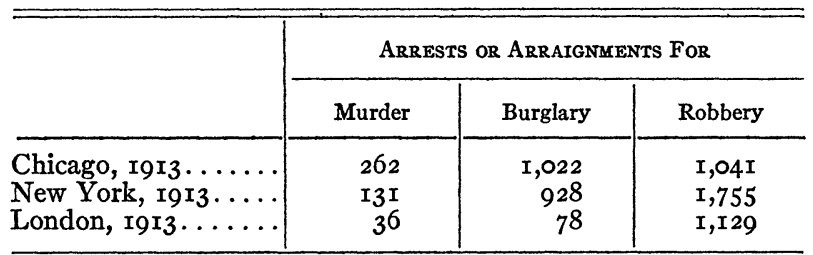

"Of those arrested 64.7 per cent are native Americans, and 35.3 per cent foreign born, the relative percentage of population being 53.2 per cent and 46.8 per cent (population over fifteen years of age taken as basis)." 